Asian J Agric \& Biol. 2022(1).

$\mathrm{AJAB}$

DOI: $10.35495 / a j a b .2020 .07 .391$

Original Article

\title{
Investigation of antioxidant and anti-hemolytic properties of Algerian Bunium incrassatum tubers and their effects as diet on histological and biochemical parameters of normal Wistar rats
}

\author{
Farid Berroukeche ${ }^{1,2^{*}}$, Nawel Attoui ${ }^{3}$, Fethi Toul ${ }^{4}$, Mohammed Ziane ${ }^{5,6}$, Nassima Mokhtari Soulimane ${ }^{1}$, \\ Hafida Merzouk ${ }^{1}$ \\ ${ }^{1}$ Laboratory of Physiology, Pathophysiology and Biochemistry of Nutrition, Department of Biology, Faculty of Nature and \\ Life Sciences, Earth and Universe, University of Tlemcen 13000, Algeria \\ ${ }^{2}$ Faculty of Medicine, University of TAHRI Mohammed, Bechar, Algeria \\ ${ }^{3}$ Laboratory of Vegetal Resources Valorization and Food Security in Semi-Arid Areas South West of Algeria Department of \\ Biology, Faculty of Nature and Life Sciences, , University of TAHRI Mohammed Bechar, Algeria \\ ${ }^{4}$ Laboratory of Chemistry and Environmental Sciences, Faculty of Nature and Life Sciences, University of TAHRI \\ Mohammed, Bechar, Algeria \\ ${ }^{5}$ University Center of Ain Temouchent, Sidi bel Abbes Road, N101, Ain Temouchent, Algeria \\ ${ }^{6}$ Laboratory of Microbiology Applied to Agri-food, Biomedical and Environment (LAMAABE), Faculty of SNV / STU, \\ University of Tlemcen, Algeria
}

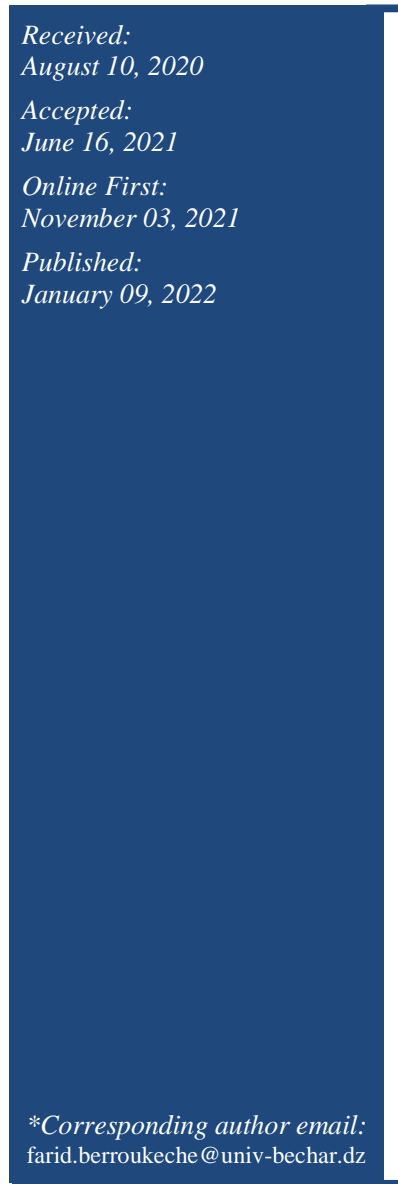

\begin{abstract}
The present study aimed at determining the effectiveness of Bunium incrassatum acetonic and ethanolic tuber extracts as antioxidant (DPPH assay) and anti-hemolytic agents (hypotonic solution, $\mathrm{H}_{2} \mathrm{O}_{2}$ and triton X100 assays) and tubers' powder as dietary supplement on body weight, on histological (liver, thyroid, testes, and kidney) and biochemical parameters (glycaemia, cholesterol, triglycerides, urea, creatinine, HDL, LDL, AST and ALT). In DPPH assay, acetonic extract $\left(\mathrm{IC}_{50}=0.02 \mathrm{mg} / \mathrm{ml}\right)$ exhibited by far, higher scavenging potential, even compared to ethanolic extract $\left(\mathrm{IC}_{50}=0.19 \mathrm{mg} / \mathrm{ml}\right)$ and ascorbic acid $\left(\mathrm{IC}_{50}=0.25 \mathrm{mg} / \mathrm{ml}\right)$ as reference compound. The same extract showed a very good protective effect against hemolysis induced by $\mathrm{H}_{2} \mathrm{O}_{2}$ and hypotonic solutions with $76.43 \% \pm 3.71$ and $77.67 \% \pm 2.07$ $\mathrm{mg} / \mathrm{mL}$, respectively and closely followed by quercetin as reference compound. The in vivo results revealed that rats receiving orally $15 \%$ of $B$. incrassatum with diet (BID group) during 15 days of experimentation increased significantly their final body weight $(98.88 \%)$. Then, a significant rise of glycaemia (+17.92\%), HDLc (+25\%), AST $(+36.78 \%)$ and ALT $(+56.76 \%)$ levels associated to a notable decrease of triglycerides $(-29.1 \%)$ and creatinine $(-12.74 \%)$ were observed compared with control animals. These promising findings support the traditional use of $B$. incrassatum tubers as functional food for human and farm animals, and suggest that their radical scavenging and anti-hemolytic potentials are may be due to the presence of polyphenolic compounds.
\end{abstract}

Keywords: Bunium incrassatum, Histology, Diet, Antihemolytic, Antioxidant, Wistar rats

\section{How to cite this:}

Berroukeche F, Attoui N, Toul F, Ziane M, Soulimane MN and Merzouk H, 2022. Identification of non-coding RNAs in the hyper thermophilic bacterium Thermotoga maritima MSB8 through comparative genomics and in-silico analyses. Asian J. Agric. Biol. 2022(1): 202007391. DOI: https://doi.org/10.35495/ajab.2020.07.391

This is an Open Access article distributed under the terms of the Creative Commons Attribution 3.0 License. (https://creativecommons.org/licenses/by/3.0), which permits unrestricted use, distribution, and reproduction in any medium, provided the original work is properly cited. 


\section{Introduction}

Secondary plant metabolites also known as natural products are rich sources of bioactive substances, like polyphenols and essential oils which have shown to possess numerous beneficial health effects including antioxidant (Nahdi et al., 2018), antihemolytic (Manthra et al., 2019), antimicrobial (Bousetla et al., 2015) and cyto-selective anticancer activities (Afsar et al., 2016). In the past, the important role of phytotherapy and folk medicinal plants was often overlooked and underestimated. Nowadays, renewed interest among the scientific and public community on traditional medicinal plants has been gained a respectable place (Karunamoorthi et al., 2013). Bunium incrassatum (Boiss), Batt and Trab, commonly called "Talghouda", is one among these economically important medicinal plants belonging to Umbelliferae (Apiaceae) family. Widely distributed in the north parts of Algeria, Bunium, this genus encloses seven species in Algerian flora, four of them are endemic (Bousetla et al., 2015; Lefahal et al., 2017). B. incrassatum tubers (tuberous roots) are very nutritious, traditionally cooked like potatoes and often consumed fresh. Dried and powdered tubers are used for their astringent, anti-diarrheal and antiinflammatory effects and even against hemorrhoids in the indigenous medicines. Further, they are used mostly for treating bronchitis and cough. According to traditional agriculture, B. incrassatum is used to increase weight and milk secretion of certain farm animals. In previous studies, phytochemical analysis of $B$. incrassatum revealed the presence of many bioactive and nutritional compounds like sucrose, oleic acid, scopoletin, $\beta$-sitosterol and scoparone (Bousetla et al., 2015; Chentouh et al., 2017).

Since the plant-derived products became a source of novel therapeutics and in order to exploit Algerian local species, the main aim of this research is to investigate the in vivo effects of tuber powder as diet on histological and biochemical parameters of normal Wistar rats. In the same time, the in vitro effects of ethanolic and acetonic extracts of $B$. incrassatum tubers in human red blood cells were also studied, which, as far as our knowledge is concerned, had never been explored before.

\section{Material and Methods}

\section{In vitro study \\ Biological material}

Tubers of Bunium incrassatum were collected in September 2019 from Tlemcen, Algeria. They were identified by an expert in botany, washed thoroughly with water, dried in shadow at room temperature for few days, ground into fine powder and stored at room temperature in sealed flasks under dark conditions.

\section{Preparation of the extracts}

Two $50 \mathrm{~g}$ of shade dried and grounded tubers were macerated in $500 \mathrm{ml}$ of ethanol $70 \%$ and $500 \mathrm{ml}$ of acetone separately, for 48 hours with constant stirring at room temperature and then filtered. The filtrates were concentrated until dryness using a vacuum rotary evaporator Type BUCHI at $60^{\circ} \mathrm{C}$. The obtained residues were conserved be used later for in vivo and in vitro analyses.

\section{In vitro 2, 2-diphenyl-1-picrylhydrazyl (DPPH) scavenging activity}

DPPH assay was adopted from previous studies (Manthra et al., 2019) for evaluating the inhibitory activity of ethanolic and acetonic extracts of $B$. incrassatum against DPPH radical. $100 \mu \mathrm{L}$ of different concentrations, ranging from 0.2 to 1 $\mathrm{mg} / \mathrm{mL}$, of each extract was added to $1 \mathrm{ml}$ of 0.135 $\mathrm{mM}$ methanolic DPPH solution. The mixture was placed in the dark at room temperature for $30 \mathrm{~min}$. The absorbance was measured at $515 \mathrm{~nm}$. Ascorbic acid was taken as reference standard. The inhibition percentage was calculated using the following formula:

$$
\% \text { Radical scavenging activity }=\frac{A b s_{c}-A b s_{s p l}}{A b s_{c}} \times 100
$$

$A b s_{c}$ : Control's absorbance.

$A b s_{s p l}$ : Sample's/standard's absorbance.

Mean values were obtained from triplicate experiments. IC50 (concentration of the sample which induces $50 \%$ inhibition) of each sample was calculated from the graph plotting inhibition percentage against extract concentration $(\mathrm{mg} / \mathrm{ml})$.

\section{Preparation of erythrocyte suspension}

Blood samples from healthy volunteers, after taking informed consent, were collected in tubes containing heparin. After being gently mixed by repeated inversion, tubes were centrifuged at $1500 \mathrm{rpm}$ for 10 min at $4^{\circ} \mathrm{C}$ and the plasma was discarded. Then erythrocytes were washed 3 times with 2 volumes of $10 \mathrm{mM}$ Phosphate-buffered saline (1X PBS: $150 \mathrm{mM}$ 
$\mathrm{NaCl}, 1.9 \mathrm{mM} \mathrm{NaH} \mathrm{PO}_{4}, 8.1 \mathrm{mM} \mathrm{Na} \mathrm{HPO}_{4}, \mathrm{pH} 7.4$ ) and centrifuged at $1500 \mathrm{rpm}$ for $5 \mathrm{~min}$. The supernatant was carefully removed after each centrifugation. The cells were resuspended in PBS at a hematocrit of $10 \%$ and used immediately for the evaluation of antihemolytic potential.

\section{Effect of tuber extracts on hemolysis induced by hypotonic solution}

The anti-hemolytic activity assessment was performed using three different methods.

The reaction mixture consists of $100 \mu$ l of different concentrations of sample from 0.1 to $1(\mathrm{mg} / \mathrm{mL})$ and $100 \mu \mathrm{l}$ of $10 \%$ red blood cells (RBC) suspension. After 10 minutes incubation, $0.5 \mathrm{~mL}$ of hyposaline water $(\mathrm{NaCl}, 3.5 \mathrm{mg} / \mathrm{ml})$ was added. Control (negative control) without extracts and standard (quercetin as positive control) were prepared. The mixture was incubated at $37 \mathrm{C}^{\circ}$ for $30 \mathrm{~min}$ and centrifuged at 3000 $\mathrm{rpm}$ for $10 \mathrm{~min}$. The supernatant hemoglobin content was estimated spectrophotometrically at $540 \mathrm{~nm}$ (Louerrad et al., 2016).

\section{Effect of tuber extracts on hemolysis induced by $\mathrm{H}_{2} \mathrm{O}_{2}$}

Anti-hemolytic potential of ethanolic and acetonic extracts were assessed by spectrophotometric procedure as described previously (James and Alewo, 2014). Briefly, $250 \mu \mathrm{L}$ of $10 \% \mathrm{RBC}$ suspension was added to $500 \mu \mathrm{L}$ of different extract concentrations $(0.1-1 \mathrm{mg} / \mathrm{mL}$ in PBS) and incubated for 30 minutes at room temperature. After that, $500 \mu \mathrm{l}$ of $1 / 30 \mathrm{H}_{2} \mathrm{O}_{2}$ ( $30 \% \mathrm{w} / \mathrm{w}$ in $\mathrm{H}_{2} \mathrm{O}$ ) was added and incubated for 3 hours in water bath at $37 \mathrm{C}^{\circ}$. The final volume of each tube was adjusted to $4.5 \mathrm{~mL}$ with PBS and centrifuged at $3000 \mathrm{rpm}$ for $10 \mathrm{~min}$. Distilled water was used as blank. The supernatant hemoglobin content was estimated spectrophotometrically at $540 \mathrm{~nm}$. For negative control the relative hemolysis was estimated in comparison with the hemolysis in the $\mathrm{H}_{2} \mathrm{O}_{2}$ treated, which was set as $100 \%$. Then, phosphate-buffered saline was used as positive control. Each series of samples was conducted in triplicate and the inhibitory activity of different fractions was calculated and expressed as percent inhibition of hemolysis. However, quercetin $(0.1-1 \mathrm{mg} / \mathrm{ml})$ was used as a reference compound.

\section{Effect of tuber extracts on hemolysis induced by triton X100}

The preparation of RBC suspension was carried out as described above. In a series of test tubes, $1 \mathrm{~mL}$ of different concentrations of tuber extracts (0.1$1 \mathrm{mg} / \mathrm{mL}$ ) was added to $500 \mu \mathrm{L}$ of $\mathrm{RBC}$ suspension. The mixture was incubated for 10 minutes at room temperature, after being gently mixed. Then, $800 \mu \mathrm{L}$ of $1 \%(\mathrm{w} / \mathrm{v})$ Triton $\mathrm{X}-100$ was added to the reaction mixture, incubated in a water bath at $37^{\circ} \mathrm{C}$ for 1 hour and centrifuged at $3000 \mathrm{rpm}$ for 10 minutes. Similarly, distilled water was used as positive control. The supernatant was collected and its absorbance was measured at $541 \mathrm{~nm}$ against PBS as blank for calculating the percentage of hemolysis (Muthu and Duraira, 2015).

The percentage of hemolysis was calculated by using the following formula;

$$
\text { Hemolysis } \%=\left(A b s_{s p l} / A b s_{c}\right) \times 100
$$

The percentage of membrane stabilization or protection was calculated by using the following formula:

$$
\text { Protection \% = } 100-[\text { hemolysis \%] }
$$

\section{In vivo study \\ Animals and diet preparation}

Twelve male Wistar rats (08 weeks-old), weighing between 90 and $100 \mathrm{~g}$ were obtained from Pasteur Institute of Algeria, placed in stainless steel cages and kept in a controlled environment under standard conditions of temperature $\left(23 \pm 2{ }^{\circ} \mathrm{C}\right)$, humidity $(55 \pm$ $5 \%)$ and light $(12 / 12 \mathrm{~h}$ light/dark cycle) to respect their biological clock. Rats were acclimatized in the laboratory for a period of one week before the beginning of the study which, they received a standard diet (ONAB) and water ad libitum. Animal experimentation was conducted in accordance with the approved procedures of the animal care committee of the Faculty of Nature, Life, Earth and Universe Sciences, Tlemcen University, Algeria.

Animals used in this study were divided into two cages of 6 rats each. The first cage received a standard diet (ONAB) and the second cages male received a standard diet enriched with $15 \%$ of $B$. incrassatum tubers (85\% of ONAB standard diet and $15 \%$ of $B$. incrassatum tubers' powder). In parallel, during 15 days of experimentation, rats were weighed regularly:

- Group I: CD, Control Diet $(\mathrm{n}=06)$ : received standard 
$\operatorname{diet}(\mathrm{ONAB})$;

- Group II: BID, B. incrassatum diet: received standard diet supplemented with $15 \%$ of $B$. incrassatum.

Sacrifice and Blood collection

After 15 days of experimentation rats were anesthetized and sacrificed. The blood was immediately collected in heparinized tubes. After centrifugation at $3000 \mathrm{rpm}$ for 10 minutes, the obtained plasma was collected in dry tubesand stored at $-4^{\circ} \mathrm{C}$, for biochemical analysis. Glucose, urea creatinine, Cholesterol (CHOL), triglycerides (TG) and HDL (High-density lipoprotein), LDL (Lowdensity lipoprotein), aspartate aminotransferase (AST) and alanine aminotransferase (ALT) contents were assessed using Spinreact Kits, spain.

\section{Histopathological examination}

After necropsy, samples from liver, thyroid, testes, and kidney were collected, washed in serum saline and weighed for histological studies. The relative weight (RW) of each organ was determined by the following formula:

\section{Relative weight $(\mathrm{g} / \mathbf{1 0 0 g})=($ Organ weight $\mathrm{g} /$ Body weight g) $x 100$}

After that, collected samples were fixed in buffered formalin (10\%) for at least $24 \mathrm{~h}$ then dehydrated in a graded series of ethanol, cleared in xylene, embedded in paraffin wax, cut in 4-5 $\mu \mathrm{m}$ sections and stained with the Hematoxylin and Eosin (H\&E).

\section{Microscope photography}

The photomicrographs were conducted with an optical microscope (Zeiss) equipped with a digital camera.

\section{Statistical analysis}

The statistical analysis was performed by the student's T test. Data were analyzed using Graph Pad Prism 7 and Excel 2016 software and results were given in the form of averages and standard errors of means (MEAN \pm SEM). Comparison or correlation is considered, according to the probability (p), as follows: Not significant if $p>0.05$, significant $(*)$ if $\mathrm{p}<0.05$, highly significant $(* *)$ if $\mathrm{p}<0.01$ and very highly significant $(* * *)$ if $\mathrm{p}<0.001$.

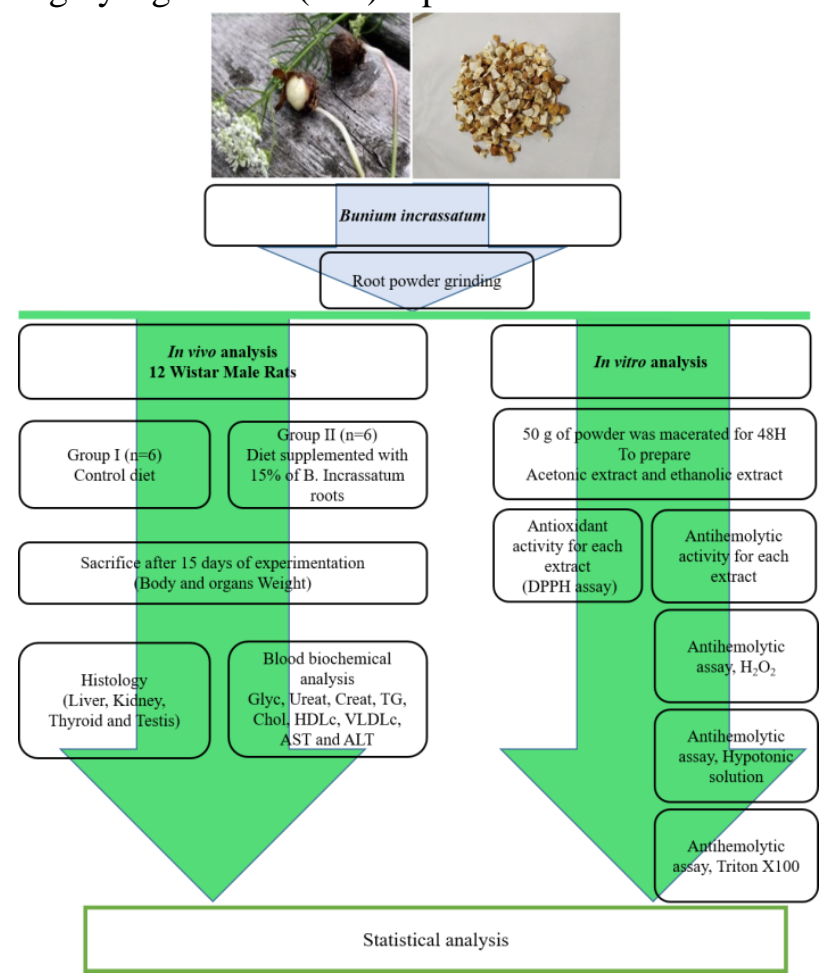

Figure-1: Summary of experimental protocol.

\section{Results}

\section{In vitro study DPPH essay}

Antioxidant activity of ethanolic and acetonic extracts of $B$. incrassatum was evaluated through their ability to scavenge DPPH free radicals. Inhibition concentration of each extract $\left(\mathrm{IC}_{50}\right)$ was calculated as antioxidants that are necessary to decrease the initial DPPH concentration by 50\%. The results of this test as shown in Table 1indicated that acetonic extract $\left(\mathrm{IC}_{50}=0.04 \mathrm{mg} / \mathrm{ml}\right)$ is more effective to scavenge DPPH radical than ethanolic extract $(\mathrm{IC} 50=0.19 \mathrm{mg} / \mathrm{ml})$ even compared to reference standard $(0.25 \mathrm{mg} / \mathrm{ml}$ for ascorbic acid). 
Farid Berroukeche et al.

Table-1: DPPH scavenging of ethanolic and acetonic extract of $B$. incrassatum roots.

\begin{tabular}{|c|c|c|c|c|c|c|c|c|}
\hline $\begin{array}{c}\text { Concentration } \\
(\mathrm{mg} / \mathrm{ml})\end{array}$ & 0,0156 & 0,0312 & 0,0625 & 0,125 & 0,25 & 0,5 & 1 & $\begin{array}{c}\mathrm{IC}_{50} \\
\text { Value }\end{array}$ \\
\hline $\begin{array}{c}\text { Acide } \\
\text { Ascorbique }\end{array}$ & $29,25 \pm 0.13$ & $36,57 \pm 0.14$ & $44,76 \pm 1.36$ & $45.01 \pm 1.45$ & $50.13 \pm 0.92$ & $75,98 \pm 2.12$ & $40,61 \pm 2.03$ & 0.25 \\
\hline $\begin{array}{c}\text { Acetonic } \\
\text { extract }\end{array}$ & $47.02 \pm 1.9$ & $49.04 \pm 0.33$ & $52.62 \pm 2.45$ & $59.29 \pm 2.34$ & $64.14 \pm 2.21$ & $73.12 \pm 2.36$ & $75.54 \pm 1.14$ & 0.04 \\
\hline $\begin{array}{c}\text { Ethanolic } \\
\text { extract }\end{array}$ & $29,36 \pm 1.12$ & $36,89 \pm 0.17$ & $42,9 \pm 0.34$ & $45,08 \pm 1.52$ & $55,3 \pm 3.29$ & $60.01 \pm 3.02$ & $58,9 \pm 1.87$ & 0.19 \\
\hline
\end{tabular}

NB: Results are expressed in $\%$ and the $\mathrm{IC}_{50}$ in $\mathrm{mg} / \mathrm{ml}$

Effect of tuber extracts on hemolysis induced by hypotonic solution, $\mathrm{H}_{2} \mathrm{O}_{2}$ and Triton $\mathrm{X100}$

As illustrated below in Figure 2, the hypotonic solution $(3.5 \mathrm{mg} / \mathrm{ml}), \mathrm{H}_{2} \mathrm{O}_{2}(1 / 30)$ and Triton $\mathrm{X} 1 \%$ (w/v) exhibited a potent hemolytic activity on human erythrocytes. However, that hemolytic effect was reduced by ethanolic and acetonic extracts in a dose dependent manner in the three hemolytic methods.

The maximum hypotonic membrane fragility protection was observed with acetonic extract $(76.43 \% \pm 3.71)$ and quercetin as a positive control $(76.91 \% \pm 3.87)$ at a concentration of $1 \mathrm{mg} / \mathrm{mL}$.

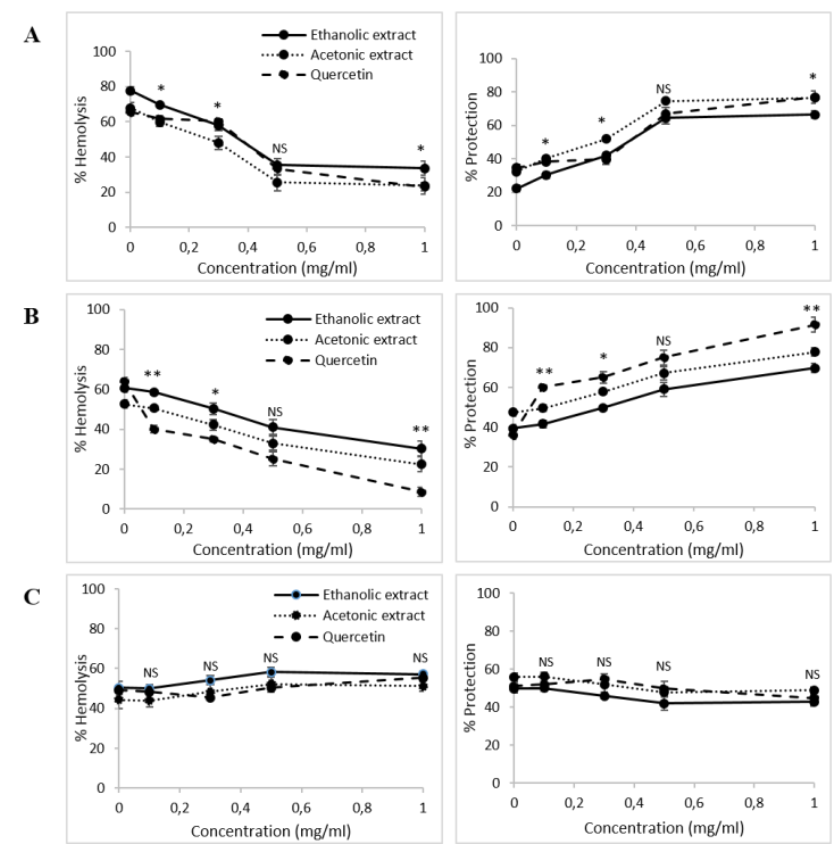

Figure-2: Effect of $B$. incrassatum tuber extracts on human erythrocytes hemolysis. (A),Hemolysis induced by hypotonic solution; (B), Hemolysis induced by hydrogen peroxide; (C), Hemolysis induced by Triton X100.The Data was represented as Mean \pm SEM. Experiment was done in triplicates; $\mathbf{n}=\mathbf{3}$.
Further, high rate of protection against erythrocytes membrane damage induced by $\mathrm{H}_{2} \mathrm{O}_{2}$ was observed in quercetin $(91.5 \% \pm 3.87)$ followed by acetonic extract $(77.67 \% \pm 2.07)$ whereas the ethanolic extract exhibited less protection effect $(69.67 \% \pm 2.19)$. However, no significant protective effect $(P>0.05)$ was observed on both tuber extracts in hemolysis assay induced by Triton X100 on all plant extract concentration series Figure-2.

\section{In vivo study}

Body weight evolution and relative organ weight (g/100g of b.w)

Figure 3 and table 2 reveal respectively the evolution of rats body weight and relative organs weight of those that received $15 \%(\mathrm{w} / \mathrm{w})$ of $B$. incrassatum with diet (BID) compared to control during 15 days of experimentation. Results showed a significant increase in the final body weight of BID (98.88\%) and control groups (77.07\%) as compared to the initial body weight (Figure 3 ).

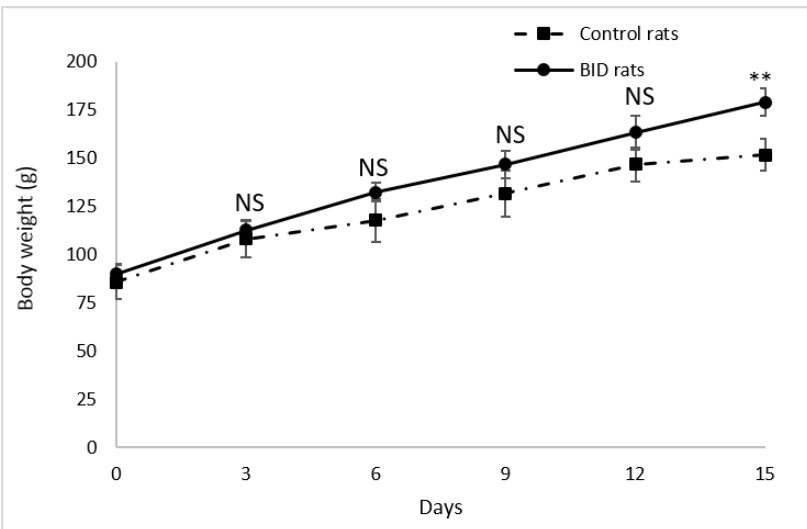

Figure-3: Body weight evolution of rats during 15 days of experimentation

However, data of relative body weight demonstrated a significant reduce of kidney weight of BID rats 
compared with control group (Table 2). No significant changes were observed in liver, thyroid and testes relative weight of BID animal compared with control rats.

Table-2: Organs relative weight $(\mathrm{g} / \mathrm{100g})$ of studied rats

\begin{tabular}{|c|c|c|}
\hline Organs & CD & BID \\
\hline Liver & $4,70 \pm 0,24$ & $4,79 \pm 0,20^{\mathrm{NS}}$ \\
\hline Kidney & $0,94 \pm 0,04$ & $0,85 \pm 0,03^{*}$ \\
\hline Thyroid & $0,10 \pm 0,02$ & $0,12 \pm 0,01^{\mathrm{NS}}$ \\
\hline Testis & $1,63 \pm 0,05$ & $1,76 \pm 0,04^{\mathrm{NS}}$ \\
\hline
\end{tabular}

The obtained results of plasma biochemical analyses are shown in Table 3. A significant rise of glycaemia, HDLc, AST and ALT levels in BID animals compared with control rats. However, a notable decrease of creatinine and TG was shown in BID group compared with control animals.

Table-3: Biochemical analysis of rats during 15 days of experimentation

\begin{tabular}{|c|c|c|}
\hline $\begin{array}{c}\text { Biochemical } \\
\text { parameters }\end{array}$ & CD & BID \\
\hline Glyc $(\mathrm{g} / \mathrm{L})$ & $1,06 \pm 0,02$ & $1,25 \pm 0,03^{* * *}$ \\
\hline Urea $(\mathrm{g} / \mathrm{L})$ & $0,46 \pm 0,02$ & $0,42 \pm 0,03^{\mathrm{NS}}$ \\
\hline Creat $(\mathrm{mg} / \mathrm{L})$ & $5,81 \pm 0,25$ & $5,07 \pm 0,05^{*}$ \\
\hline $\mathrm{TG}(\mathrm{g} / \mathrm{L})$ & $1,34 \pm 0,06$ & $0,95 \pm 0,03^{* * *}$ \\
\hline Chol $(\mathrm{g} / \mathrm{L})$ & $0,76 \pm 0,04$ & $0,76 \pm 0,02^{\mathrm{NS}}$ \\
\hline $\mathrm{LDLc}(\mathrm{g} / \mathrm{L})$ & $0,21 \pm 0,03$ & $0,22 \pm 0,02^{\mathrm{NS}}$ \\
\hline $\mathrm{HDLc}(\mathrm{g} / \mathrm{L})$ & $0,28 \pm 0,03$ & $0,35 \pm 0,01^{* *}$ \\
\hline $\mathrm{AST}(\mathrm{IU} / \mathrm{L})$ & $87 \pm 8,25$ & $119 \pm 15.32^{* * *}$ \\
\hline $\mathrm{ALT}(\mathrm{IU} / \mathrm{L})$ & $37 \pm 1,01$ & $58 \pm 1,6^{* * *}$ \\
\hline
\end{tabular}

\section{Histological changes analysis}

\section{Liver}

Liver sections of control, and BID rats revealed normal histological structure of hepatic lobules. Liver cells arranged in trabeculae running radiantly from the central vein and disconnected by sinusoids usually, containing Kupffer cells. Hepatocytes were regular, containing a large spheroidal nucleus with a distinctive marked nucleolus and peripheral chromatin distribution. Some cells had two nuclei each embedded in connective tissue.

\section{Kidney (cortical part)}

Renal glomeruli showed normal structure in both groups (control and BID). Tubules were wrinkled with typical thick cubic epithelium with a relatively regular distinct lumen. Lobular organization of the glomeruli and a flat epithelium lining the glomerular capsule could be seen.

\section{Thyroid}

Thyroid glands from control and BID animals showed normal histological appearance, with cuboidal to low columnar epithelium lining, small and medium-sized follicles, and lower epithelium lining large follicles. The observation demonstrated a rise in the number of follicles with reduced colloids in BID group compared with control rats.

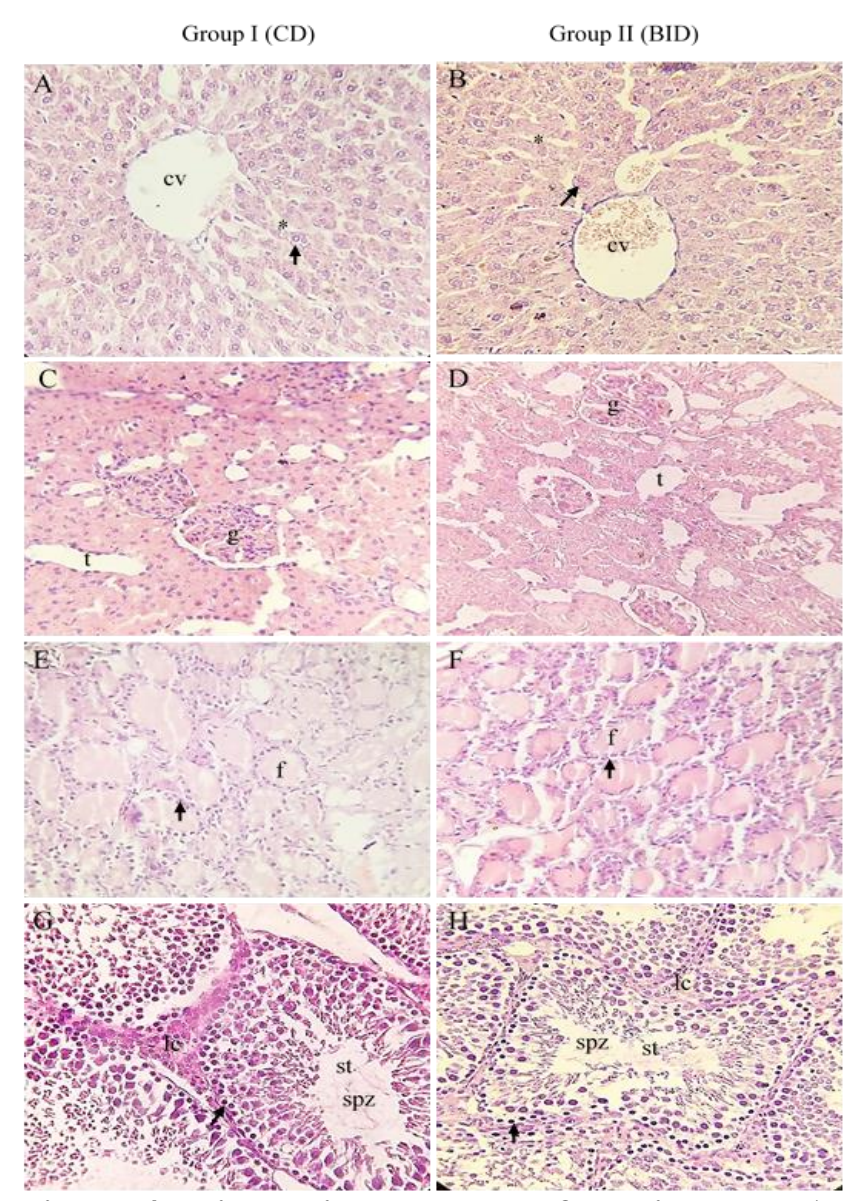

Figure-4: Histological changes of studied rats. AB liver: (arrow) binucleated hepatocyte, (cv) centrolobular vein, (*) trabicules; C-D kidney: (g) glomeruli, (t) tubular; E-F thyroid: (f) follicule, (arrow) thyrocyte; G-H testis: (spz) mature Spermatozoa, (st) seminiferous tube, (lc) Leydig cells, (arrow) spermatogonie. Hematoxylin \& Eosin stain, 400X. 


\section{Testes}

A transverse section in rat testes of control and experimental groups showed a range of differences in the size, shape, uniformity and undisturbed pattern in seminiferous tubular arrangement. Control group rats compared to BID showed layers distribution of epithelium cells in their different stages inside the seminiferous tubule with a predominance of spermatogonia and spermatids.

\section{Discussion}

Bunium species have been widely used for their nutritional and medical values in different countries especially in Algeria. DPPH radical scavenging test is one of the most widely used procedures to evaluate antioxidant potency of plant and biological samples. According to calculated $\mathrm{IC}_{50}$, of DPPH scavenging assay of different $B$. incrassatum tuber extracts, results showed that acetonic extract $\left(\mathrm{IC}_{50}=0.04\right.$ $\mathrm{mg} / \mathrm{ml}$ ) is the most effective one by far even compared to ascorbic acid $\left(\mathrm{IC}_{50}=0.25 \mathrm{mg} / \mathrm{ml}\right)$. This variance in antioxidant potential shown between extracts is closely linked to the phytochemical composition and to the different solvent polarities used to extract bioactive antioxidant compounds (Afsar et al., 2016). Previous phytochemical analyses of $B$. incrassatum revealed the presence of various bioactive phyetochemicals such as sucrose, scopoletin, oleic acid, scoparone and $\beta$-sitosterol (Bousetla et al., 2015). Furthermore, the presence of some molecules, even in minority, such as thymol and carvacrol was marked to attribute a high degree of antioxidant potential through synergy against free radicals like DPPH (El Kolli et al., 2017). Erythrocyte hemolysis susceptibility to toxic substances such as hypotonic medium and $\mathrm{H}_{2} \mathrm{O}_{2}$ solution is one of the most used methods to evaluate in vitro lysis of the membranes (Afsar et al., 2016; Debnath et al., 2013; Dima et al., 2017). Inflammatory (Dima et al., 2017) and oxidative damage of lipids and proteins of erythrocyte membrane may indeed be responsible of hemolysis.(Afsar et al., 2016). As shown in results of anti-hemolytic activity of acetonic and ethanolic extracts against hemolysis induced $\mathrm{byH}_{2} \mathrm{O}_{2}$ and hypotonic solutions, the maximum of hypotonic membrane fragility protection was observed in acetonic extract $(76.43 \% \pm 3.71)$, closely followed by quercetin as positive control $(76.91 \% \pm 3.87)$ at $1 \mathrm{mg} / \mathrm{ml}$. However, the protective effect of our extracts against $\mathrm{H}_{2} \mathrm{O}_{2}$ erythrocytes membrane damage indicated that ethanolic extract $(69.67 \% \pm 2.19)$ had less protective effect than acetonic extract $(77.67 \% \pm 2.07) \quad$ compared with quercetin $(91.5 \% \pm 3.87)$ as positive control. A number of studies confirmed the stabilizing action of tannins and flavonoids on red blood cell membrane lysis in hypotonic medium (Awe et al., 2009; Oyedapo et al., 2015).

Literature reported the existence of many similarities between erythrocytic and lysosomal membranes. The effect of drugs on erythrocyte stabilization may be extrapolated to lysosomal membrane stabilization. In fact, saving lysosomal membrane integrality is important in inflammatory response via preventing the release of lysosomal contents such as bactericidal enzymes and proteases of activated neutrophils, which leads to spread tissue damage and inflammation (Shirwaikar et al., 2011). Furthermore, the presence of polyunsaturated fatty acids in erythrocyte membranes makes it vulnerable to free radical attack. In the present study, erythrocyte lipid oxidation induced by peroxy radicals (ROO-) generated from $\mathrm{H}_{2} \mathrm{O}_{2}$ exposition leads to erythrocytes hemolysis (Sasikumar et al., 2012). The in vitro membrane stabilizing properties of acetonic and ethanolic extracts were observed by their ability to enhance protection against $\mathrm{H}_{2} \mathrm{O}_{2}$ and to reduce erythrocyte hemolysis which was displayed to be decreased with an increasing concentration of extracts (Afsar et al., 2016). This may be due to the radical scavenging activity of the bioactive compounds present in the extracts (Khalili et al., 2014). Furthermore, phenolic compounds are good hydrogen and electron atom donors, and can thus, interrupt the radical chain reaction by transforming free radicals and reactive oxygen species into more stable products (Dima et al., 2017). Our results are in agreement with studies suggesting that phenolic compounds protect erythrocyte cells from inflammation and oxidative stress by rising membrane resistance to oxidative damage.

The in vivo side of our study revealed that rats receiving orally $15 \%(\mathrm{w} / \mathrm{w})$ of $B$. incrassatum with diet (BID) during 15 days of experimentation increased significantly in their final body weight (98.88\%) as compared to the initial body weight and control animals.

To our knowledge, this study is the first of its kind evaluating the effect of $B$. incrassatum tubers on body weight evolution in Wistar rats. However, 
Chentouh et al. demonstrated that oral administration of organic extract of $B$. incrassatum in female rabbit during 15 days increase final body weight of control and treated animals as compared with its respective initial body weight but this weight evolution isn't statistically significant (Chentouh et al., 2017). Unlike our study and despite of its the short duration, the significant evolution of body weight observed in BID rats compared with control may be justified by the presence of high level of starch, sucrose or appetogenic phytochemical compounds involved in food uptake stimulation.

The present study reveal also that BID group present a significant rise of glycaemia $(+17.92 \%)$, HDLc $(+25 \%)$, AST $(+36.78 \%)$ and ALT $(+56.76 \%)$ levels associated with a notable decrease of TG (-29.1\%) and creatinine $(-12.74 \%)$ compared with control animals.

Many plants had been studied for their hypoglycaemic and insulin release stimulatory effects. Nonetheless, it is possible to cite some reports that have attributed such effects to some medicinal plants (Lozoya-Meckes and MelladoCampos, 1985; Morrison and West, 1985, Morrison et al., 1987). The common probable mechanism implicated in the enhancement of blood glucose level is inhibition of insulin release (Al-Hader et al., 1994). Further experiments are required to confirm these results especially the effect of Bunium genius plants on thyroid hormones dysfunction at different doses.

The nutraceutical beneficial effects of $\beta$-sitosterol (one of Bunium's components) are well documented. Chai et al., study explained that he supplementation of margarine, butter, and orange juice with $\beta$ sitosterol have shown to reduce LDL cholesterol. In vivo study, it was estimated that only $4 \%$ of $\beta$ sitosterol is absorbed in rats, which is shown that oral $\beta$-sitosterol intake increased fasting insulin level, decreased fasting glucose level, and increased insulin release from isolated rat pancreatic islet cells. However pretreatment of preadipocytes, 3T3-L1 with $\beta$-sitosterol impaired cells growth, but co-incubated with oleic acid, it induced accumulation of triglyceride. (Chai et al., 2011). However, rise of HDLc level associated with no significant value of plasma cholesterol and LDLc may be a sign of protection or physiological response to an acute dyslipidemia situation probably unclear during fifteen days of experimentation.

Liver and kidney play pivotal roles in metabolic processes and its health status evaluation requires many blood biomarkers (Olayode et al., 2019). However, for kidney dysfunction assessment, the retention of creatinine, electrolytes, urea and uric acid in the body were usually estimated (Unuofin et al., 2018). Olayode et al. explained that, in the first phase of kidney toxicity, plasma creatinine is a better indicator parameter than urea (Olayode et al., 2019).These results agree with obtained kidney relative weight which we had shown a significant decrease.

In this study, BID enhanced significantly ALT and AST activities, which are used as markers of liver cell damage. In fact, ALT is an intracellular enzyme released into the blood by hepatocytes in the event of necrosis. This is a particular enzyme of the liver, allowing it a very sensitive marker of hepatotoxicity (Kumar et al., 2018). AST is also a predictor parameter of hepatocyte damage, which it's present also in the skeletal muscle, heart, lungs and kidneys (Nahdi et al., 2018).

The present study was undertaken to evaluate also the histomorphometric changes of liver, kidney, thyroid and testes of studied rats. No significant structure changes were observed in liver and kidney organs between control and BID rats during the period of study. However, a rise of number of thyroid follicles with reduced colloids in BID group compared with control rats were observed.

Thyroid hormone is a relevant regulator of metabolism and growth in approximately of all body tissues, and slight changes in thyroid function affect many organs and systems. In fact, previous study has reported that thyroid hormone affects both steroidogenesis and spermatogenesis. The presence of triiodothyronine (T3) in the regulation of Sertoli cells proliferation and functional maturation is widely recognized, as well as its role in postnatal maturation of Leydig cell differentiation and steroid synthesis. The existence of thyroid hormone receptors in testicular cells during development and in adulthood means that T3 can act directly on these cells in order to achieve this effects(Wagner et al., 2008; Al Nahari and Al Eisa, 2016).

However, despite the numerous benefits of medicinal plants and it safety and no hazardous presumed effects, available evidence has shown their implication in the etiology of various types of toxicity (Kpemissi et al., 2020), making it indispensable to explore their possible toxicity (Arome and Chinedu, 2013). Furthermore, the tubers of $B$. incrassatum have been used in Algerian 
traditional folk medicine to treat thyroid disorders alone or in association with Saussurea lappa

\section{Conclusion}

Unlike the previous reports, the present study was designed to confirm the idea that Bunium incrassatum tubers can be used as a source of nutraceuticals or as a functional food to reduce the risk of chronic diseases and as a diet by providing basic nutrition.

Acetonic tuber extract played an important role against oxidation as shown by its DPPH scavenging potential, which was by far better than ascorbic acid, widely used in soft drinks, jams, condensed milk and other food products. In parallel, both tuber extracts revealed good anti-hemolytic and membrane's protective effects, close to that revealed by quercetin. $B$. incrassatum tubers' powder, as a supplement on standard diet, increased rats body weight to double in 15 days without disturbing lipid profile, which is desirable for farm animals. However, long-term investigation is required to thoroughly evaluate the safety of this supplementation on the evolution of body weight and on histological and biochemical parameters.

\section{Acknowledgment}

We acknowledge the assistance we received on histology from Dr. Nabila Yelles of the Department of Anatomy and Cell pathology, Faculty of Medicine, Hospital University center of Tlemcen Algeria.

Disclaimer: None.

Conflict of Interest: None.

Source of Funding: This work was financially supported by Faculty of natural science and life of Bechar University, laboratory of Physiology Pathophysiology and Biochemistry of Nutrition of Tlemcen University, and Ministry of Higher Education and Scientific Research of Algeria.

\section{References}

Afsar T, Razak S, Khan Mr, Mawash S, Almajwal A, Shabir M and Haq IU, 2016. Evaluation of antioxidant, anti-hemolytic and anticancer activity of various solvent extracts of Acacia hydaspica R. Parker aerial parts. BMC Complement. Altern. Med. 16: 258.
(Bolkiny et al., 2019; Chaturvedi et al., 1993).

Al-Hader A, Hasan Z and Aqel M, 1994. Hyperglycemic and insulin release inhibitory effects of Rosmarinus officinalis. J. Ethnopharmacol. 43: 217-221.

Al Nahari H and Al Eisa R, 2016. Effect of turmeric (Curcuma longa) on some pituitary, thyroid and testosterone hormone against aluminum chloride $(\mathrm{Al}$ [Cl. sub. 3]) induced toxicity in rat. Adv. Environ. Biol. 10: 250-262.

Arome D and Chinedu E, 2013. The importance of toxicity testing. J.P.B.S. 4: 146-148.

Awe E, Makinde J, Adeloye O and Banjoko S, 2009. Membrane stabilizing activity of Russelia equisetiformis, Schlecht \& Chan. J. Nat. Prod. 2: 3-9.

Bolkiny Y, Tousson E, El-Atrsh A, Akela M and Farg E, 2019. Costus root extract alleviates blood biochemical derangements of experimentallyinduced hypo-and hyperthyroidism in mice. Annu. Res. Rev. Biol. 1-10. DOI: 10.9734/arrb/2019/v31i530063.

Bousetla A, Zellagui A, Derouiche K and Rhouati S, 2015. Chemical constituents of the roots of Algerian Bunium incrassatum and evaluation of its antimicrobial activity. Arab. J. Chem. 8: 313-316.

Chai Jw, Lim Sl, Kanthimathi M and Kuppusamy UR, 2011. Gene regulation in $\beta$-sitosterol-mediated stimulation of adipogenesis, glucose uptake, and lipid mobilization in rat primary adipocytes. Genes. Nutr. 6: 181-188.

Chaturvedi P, Tripathi P, Pandey S, Singh U and Tripathi Y, 1993. Effect of Saussurea lappa alcoholic extract on different endocrine glands in relation to glucose metabolism in the rat. Phytother. Res. 7: 205-207.

Chentouh S, Boulahbel S, Ouldjaoui A, Hammoudi N, Djebaili $\mathrm{H}$ and Adjal F, 2017. Effect of organic extracts of Bunium incrassatum on the hematological, ovarian and uterine parameters of mature female rabbit. J. Fundam. Appl. Sci. 9: 16181633.

Debnath PC, Das A, Islam A, Islam MA, Hassan MM and Uddin SMG, 2013. Membrane stabilization-a possible mechanism of action for the antiinflammatory activity of a Bangladeshi medicinal plant: Erioglossum rubiginosum (Bara Harina). Pharmacogn. J. 5: 104-107.

Dima J, Raghda L and Abdul-Jalil G, 2017. Evaluation of hemolytic and anti-hemolytic activity of the aerial parts of Sonchus oleraceus extracts. Int. J. Phar. Sci. N. 10: 3745-3751.

El Kolli H, Laouer H and El Kolli M, 2017. Chemical composition and biological activities of the essential 
oils and the methanolic extracts of Bunium incrassatum and Bunium alpinum from Algeria. J. Chil. Chem. Soc. 62: 3335-3341.

James $\mathrm{O}$ and Alewo IM, 2014. In vitro antihemolytic activity of gymnema sylvestre extracts against hydrogen peroxide $(\mathrm{H} 2 \mathrm{O} 2)$ induced haemolysis in human erythrocytes. Am. J. Phytomed. Clin. Ther. 2: 861-869.

Karunamoorthi K, Jegajeevanram K, Vijayalakshmi J and Mengistie E, 2013. Traditional medicinal plants: a source of phytotherapeutic modality in resourceconstrained health care settings. J. Evid. Based Integr. Med. 18: 67-74.

Khalili M, Ebrahimzadeh MA and Safdari Y, 2014. Antihaemolytic activity of thirty herbal extracts in mouse red blood cells. Arh. Hig. Rada. Toksikol. 65: 399-406.

Kpemissi M, Metowogo K, Melila M, Veerapur VP, Negru M, Taulescu M, Potârniche AV, Suhas DS, Puneeth TA and Vijayakumar S, 2020. Acute and subchronic oral toxicity assessments of Combretum micranthum (Combretaceae) in Wistar rats. Toxicol. Rep. 7: 162-168.

Kumar M, Dandapat S and Sinha MP, 2018. Hepatoprotective activity of Punica granatum leaf extract against Carbon Tetrachloride induced Hepatotoxicity in Rats. Balneo. Res. J. 9: 24-27.

Lefahal M, Zaabat N, Djarri L, Benahmed M, Medjroubi K, Laouer H and Akkal S, 2017. Evaluation of the antioxidant activity of extracts and flavonoids obtained from Bunium alpinum Waldst. \& Kit.(Apiaceae) and Tamarix gallica L.(Tamaricaceae). Curr. Issues Pharm. Med. Sci. 30: 5-8.

Louerrad Y, Haddi R and Kaid HM, 2016. Etude de la peroxydation lipidique chez une plante médicinale Haloxylon scoparium Pomel. J. Biores.Val. 1: 28-33.

Lozoya-Meckes M and Mellado-Campos V, 1985. Is the Tecoma stans infusion an antidiabetic remedy? J. Ethnopharmacol. 14: 1-9.

Manthra V, Ireen C, Thilagameena S, Akshaya S, Mary AC, Giriprashanthini S and Sivasudha T, 2019. Free radical scavenging potential and antihaemolytic activity of methanolic extract of Pouteria campechiana (Kunth) Baehni. and Tricosanthes tricuspidata Linn. Biocatal. Agric. Biotechnol. 18: 101031.

Morrison E, Smith Richardson S, West ME, Brooks SE, Pascoe KO and Fletcher C, 1987. Toxicity of the hyperglycaemic-inducing extract of the annatto (Bixa orellana) in the dog. West. Indian Med. J. 36: 99-103.

Morrison E and West ME, 1985. The effect of Bixa orellana (Annatto) on blood sugar levels in the anaesthetized dog. West. Indian Med. J. 34: 38-42.

Muthu S and Duraira B, 2015. Inhibitory effect of hydroethanolic extracts of Annona muricata on human platelet aggregation and hemolysis in vitro. Int. J. Pharm. Pharm. Res. 2: 207-213.

Nahdi A, Hammami I, Ali RB, Kallech-Ziri O, El May A and El May MV, 2018. Effect of Hypericum humifusum aqueous and methanolic leaf extracts on biochemical and histological parameters in adult rats. Biomed. Pharmacother. 108: 144-152.

Olayode OA, Daniyan MO and Olayiwola G, 2019. Biochemical, hematological and histopathological evaluation of the toxicity potential of the leaf extract of Stachytarpheta cayennensis in rats. J. Tradit. Complement. Med. In press.

Oyedapo OO, Makinde AM, Ilesanmi GM, Abimbola EO, Akinwunmi KF and Akinpelu BA, 2015. Biological activities (anti-inflammatory and antioxidant) of fractions and methanolic extract of Philonotis hastate (Duby Wijk \& MargaDant). Afr. J. Tradit. Complement. Altern. Med. 12: 50-55.

Sasikumar J, Maheshu V, Smilin A, Gincy M and Joji C, 2012. Antioxidant and antihemolytic activities of common Nilgiri barberry (Berberis tinctoria Lesch.) from south India. Int. Food Res. J. 19.

Shirwaikar A, Devi S and Siju E, 2011. AntiInflammatory activity of Thespesia populnea fruits by Membrane Stabilization. Int. J. Pharmtech. Res. 3: 2060-2063.

Unuofin JO, Otunola GA and Afolayan AJ, 2018. Evaluation of acute and subacute toxicity of wholeplant aqueous extract of Vernonia mespilifolia Less. in Wistar rats. J. Integr. Med. 16: 335-341.

Wagner MS, Wajner SM and Maia AL, 2008. The role of thyroid hormone in testicular development and function. J. Endocrinol. 199: 351.

\section{Contribution of Authors}

Berroukeche F: Designed research methodology, collected and analysed data and wrote original draft of manuscript

Attoui N: Conceptualized the study, collected and interpreted data

Toul F: Interpreted data, supervised the research experiment, edited and approved manuscript

Ziane M: Collected and analysed data and contributed in manuscript write up

Soulimane MN: Conceptualized the study, collected and interpreted data

Merzouk H: Collected and analysed data and contributed in manuscript write up 
Farid Berroukeche et al. 